1 Idsoe $\mathrm{O}$, Guthe T, Willcox RR, De Weck AL. Nature and extent of penicillin side reactions, with particular reference to fatalities from anaphylactic shock. BullWHO 1968;38:159-88.

2 Sher TH. Penicillin hypersensitivity—a review. Pediatr Clin North Am 1983;30:161-76.

3 Levine BB, Kolov DM. Prediction of penicillin allergy by immunological tests. Fournal of Allergy 1969;43:231-44

4 Parker CW, Shapiro J, Kern M, Eisen HN. Hypersensitivity to pencillenic and derivatives in human beings with penicillin allergy. $\mathcal{F}$ Exp Med 1962;115:821-38.

5 Saxon A, Beall GN, Rohr AS, Adelman DC. Immediate hypersensitivity reactions to beta-lactam antibiotics. Ann Intern Med 1987;107:205-15.

6 DeSwarte RD. Drug Allergy: An Overview. Clin Rev Allergy 1986;4:143-69.

7 Green GR, Rosenblum AH, Sweet LC. Evaluation of penicillin hypersensitivity: value of clinical history and skin testing with pencilloyl-polylysine and penicillin G. $\mathcal{f}$ Allergy Clin Immunol 1977;54:19-28.

8 Warrington RJ, Simons FE, Ho HW, Gorski BA. Diagnosis of penicillin allergy by skin testing: the Manitoba experience. Can Med Assoc f 1978;118:787-91.

9 Anderson JA. Cross-sensitivity to eiphalosporins in patients allergic to penicillin. Pediatr Infect Dis 1986;5:557-61.

10 Adkinson NF Jr, Swabb EA, Sugermann AA. Immunology of the monobactam, aztreonam. Antimicrob Agents Chemother 1984;25:933-7.

11 Adkinson NF Jr. Penicillin allergy. In: Lichtenstein LM, Fauci AS, eds. Current therapy in allergy and immunology 1983-1984. Burlington, Ontario: BC Decker, 1983:57-62.

12 Ziaya PR, Hankins GDV, Gilstrap Lary C III, Halsey AB. Intravenous penicillin desensitization and treatment during pregnancy. JAMA 1986;14:2561-2.

13 Borish L, Tamir R, Rosenwasser LJ. Intravenous desensitization to betalactam antibiotics. f Allergy Clin Immunol 1987;80:314-9.

14 Sullivan TJ, Yecies LD, Shatz GS, Parker CW, Wedner HJ. Desensitization of patients allergic to penicillin using orally administered $\beta$-lactam antibiotics. F Allergy Clin Immunol 1982;69: 275-82.

15 Stark BJ, Earl HS, Gross GN, Lumry WR, Goodman EL, Sullivan TJ. Acute and chronic desensitization of penicillin-allergic patients using oral penicillin. $\mathcal{f}$ Allergy Clin Immunol 1987;79:523-32.

16 Naclerio R, Mizrahi ED, Adkinson NF Jr. Immunologic observations during desensitization and maintenance of clinical tolerance to penicillin. $\mathcal{F}$ Allergy Clin Immunol 1983;71:294-301.

\section{Tumour necrosis factor}

The term "tumour necrosis factor" was introduced to describe a serum protein produced after bacterial infections capable of causing haemorrhagic necrosis of animal tumours, a phenomenon well described in man. ${ }^{12}$ Two such proteins have now been characterised and are available as recombinant DNA derived proteins, and are referred to as tumour necrosis factor (TNF-predominantly derived from macrophages) and lymphotoxin (also called TNF $\beta$-a product of activated $\mathrm{T}$ lymphocytes). ${ }^{3-5}$ These proteins are important as mediators in immunity and inflammation, although they may also be concerned in tissue remodelling and cell differentiation. ${ }^{6-9}$ They have wide ranging effects, including modulation of the properties of vascular endothelium, induction of other cytokines, induction of antiviral activity in cells, stimulation of bone resorption, angiogenesis, and fibroblast mitogenesis. ${ }^{10-19}$

Local and transient production of tumour necrosis factor may therefore benefit the host, but generalised or sustained production may be harmful. For instance, the presence of high levels of biologically active tumour necrosis factor in serum is associated with a fatal outcome in meningococcal septicaemia. ${ }^{20}$ In addition, neutralising antibodies to tumour necrosis factor can protect animals from dying of septicaemic shock $^{21}$ and prevent the development of cerebral malaria. ${ }^{22}$ Systemic administration of tumour necrosis factor reproduces the haemodynamic and metabolic alterations seen in septicaemic shock. ${ }^{23}$ Tumour necrosis factor has been shown to play a part in the cachexia seen in animals infected with Trypanosoma bruce $i,{ }^{24}{ }^{25}$ and as it is produced by some cancer cell lines it may contribute to cancer cachexia. ${ }^{26}$

Is there a role for tumour necrosis factor in treating cancer? So far trials of recombinant tumour necrosis factor given systemically to patients with various types of cancer have yielded low response rates (less than $5 \%$ ). ${ }^{27}$ Higher rates of remission (up to $40 \%$ ) have, however, been reported after direct injection into the tumour. ${ }^{28}$ No deaths have occurred as a result of giving the factor, the most common side effects being fever, hypotension, headache, and occasional disturbances in the central nervous system. More effective regimens will probably exploit the known synergy between tumour necrosis factor and other cytokines such as interferon gamma and interleukin $2 .^{29} 30$

Tumour necrosis factor is part of a network of cell regulatory proteins collectively called cytokines, and its actions cannot be considered in isolation. Understanding cytokine interactions is likely to broaden our grasp of the pathophysiology of many diseases and enable us to use these proteins, or, alternatively, specific inhibitors of their production or actions, as therapeutic agents.

SALEEM MALIK

Clinical research fellow

FRANCES R BALKWILL

Head, biological therapies laboratory

Imperial Cancer Research Fund Laboratories,

London WC2A 3PX

1 Carswell EA, Old LJ, Kassel RL, Green S, Fiore N, Williamson BD. An endotoxin-induced crum factor that causes necrosis of tumours. Proc Natl Acad Sci USA 1975;72:3666-70.

2 Coley NH, Fowler GA, Bogatko FH. A review of the influence of bacterial infection and of bacterial products (Coley's toxins) on malignant tumors in man. Acta Med Scand 1952;145(suppl 276):29-97.

3 Beutler B, Cerami A. Cachectin and tumour necrosis factor as two sides of the same biological coin. Nature 1986;320:584-8.

4 Ruddle NH. Lymphotoxin redux. Immunology Today 1985;6:156-9.

5 Pennica D Nedwin GE, Hayflick A, et al. Human tumour necrosis factor: precursor structure, expression and homology to lymphotoxin. Nature 1984;312:724-9.

6 Shalaby MR, Aggarwal BB, Rinderknect T, Svedersky LP, Finkle BS, Palladino MA. Activation of human polymorphonuclear neutrophil functions by interferon-gamma and tumor necrosis of human polymorphonuclear neutroph

7 Ramila P, Epstein LB. Tumour necrosis factor as an immunomodulator and mediator of monocyte cytoxicity induced by itself, $\gamma$-interferon and interleukin-1. Nature 1986;323:86-9.

8 Scheurich P, Thoma B, Ucer U, Pfizenmaier K. Immunoregulatory activity of recombinan human tumour necrosis factor (TNF)- $\alpha$ : induction of TNF receptors of human T cells and TNF- $\alpha$ mediated enhancement of T cell responses. F Immunol 1987;138:1786-90.

$9 \mathrm{Kehrl} \mathrm{JH,} \mathrm{Miller} \mathrm{A,} \mathrm{Fauci} \mathrm{AS.} \mathrm{Effect} \mathrm{of} \mathrm{tumour} \mathrm{necrosis} \mathrm{factor} \mathrm{on} \mathrm{mitogen} \mathrm{activated} \mathrm{B} \mathrm{cells.}$ J Exp Med 1987;166(3):786-91.

10 Collins T, Lapierre LA, Fiers W, Strominger JL, Pober JS. Recombinant human tumor necrosis factor increases mRNA levels and surface expression of HLA-A,B antigens in vascular endothelial cells and dermal fibroblasts in vitro. Proc Natl Acad Sci USA 1986;83:446-50.

11 Bevilacqua MP, Pober JS, Majeau GR, Fiers W, Cotran RS, Gimborne MA. Recombinant tumo necrosis factor induces procoagulant activity in cultured human vascular endothelium: characterization and comparison with the actions of Interleukin 1. Proc Natl Acad Sci USA 1986;83:4533-7.

12 Pohlman TH, Stanness KA, Beatty PG, Ochs HD, Harlan JM (1986). An endothelial cell surface factor(s) induced in vitro by Lipopolysaccharide, Interleukin 1, and tumor necrosis factor- 0 factor(s) induced in vitro by Lipopolysaccharide, Interleukin 1 , and tumor necrosis factor- $\alpha$
increases neutrophil adherence by a CDw 18-dependent mechanism. F Immunol 1986;135: increases

13 Munker R, Gasson J, Ogawa M, Koeffler HP. Recombinant human TNF induces production of granulocyte-monocyte colony-stimulating factor. Nature 1986;323:79-82.

14 Nawroth PP, Bank I, Handley D, Cassimeris J, Chess L, Stern D. Tumor necrosis factor/ cachectin interacts with endothelial cell receptors to induce release of Interleukin 1. $\mathcal{F} \operatorname{Exp} M e d$ 1986;163:1363-75

15 Kohase M, Henriksen-Destefano D, May LT, Vikek J, Seghal PB. Induction of B2-interferon by tumor necrosis factor: a homeostatic mechanism in the control of cell proliferation. Cell 1986;45:659-66.

6 Wong GHW, Goeddel DV. Tumour necrosis factor alpha and beta inhibit virus replication and synergise with interferons. Nature 1986;323:819-22.

7 Bertolini DR, Nedwin GE, Bringman RS, Smith DD, Mundy GR. Stimulation of bone resorption and inhibition of bone formation in vitro by human tumour necrosis factors. Nature and inhibition

18 Leibovich SJ, Polverini PJ, Shephard MJ, Wiseman DM, Shively V, Nuseir N. Macrophageinduced angiogenesis is mediated by tumour necrosis factor-alpha. Nature 1987;329:630-2.

19 Vilcek J, Palombella VJ, Destefano DH, et al. Fibroblast growth enhancing activity of tumour necrosis factor and its relationship to other polypeptide growth factors. $f$ Exp Med $1986 ; 163: 632-3$

20 Waage A, Halstensen A, Espevik T. Association between tumour necrosis factor in serum and fatal outcome in patients with meningococcal disease. Lancet 1987;ii:355-7.

21 Beutler B, Milsark IW, Cerami AC. Passive immunization against cachectin/tumor necrosis facto protects mice from lethal effect of endotoxin. Science 1985;229:869-71

22 Grau GE, Fajardo LF, Pigeut P, Allet B, Lambert P, Vassali P. Tumour necrosis factor as an essential mediator in murine cerebral malaria. Science 1987;237:1210-2.

23 Tracey KJ, Beutler B, Lowry SF, et al. Shock and tissue injury induced by recombinant human cachectin. Science 1986;234:470-4.

24 Rouzer CA, Cerami A. Hypertriglyceridaemia associated with Trypanosoma brucei infection in rabbits: role of defective tryglyceride removal. Mol Biochem Parisitol 1980;2:31-8.

25 Beutler B, Cerami A. Identity of tumour necrosis factor and the macrophage-secreted factor cachectin. Nature 1986;319:516-8.

26 Spriggs D, Imamura K, Rodriguez G, Horiguch J, Kufe DW. Induction of tumour necrosis factor expression and resistance in a human breast tumour. Proc Natl Acad Sci USA 1987;89:6563-6.

27 Blick M, Sherwin SA, Rosenblum M, Gutterman J. Phase I study of recombinant tumor necrosis factor in cancer patients. Cancer Research 1987;47:2986-9.

28 Taguchi T. Clinical studies on recombinant human tumour necrosis factor Immunobiolog 1987;175:37.

29 Balkwill FR, Ward BG, Moodie E, Fiers W. Therapeutic potential of tumour necrosis factorand $\gamma$-interferon in experimental human ovarian cancer. Cancer Research 1987;47:4755-8.

30 Nishimura T, Ohta N, Togashi Y, Goto M, Hashimoto Y. Combination tumour-immunotherapy with recombinant tumour necrosis factor and recombinant interleukin 2 in mice. Int $\mathcal{f}$ Cancer $1987 ; 40: 255-61$ 